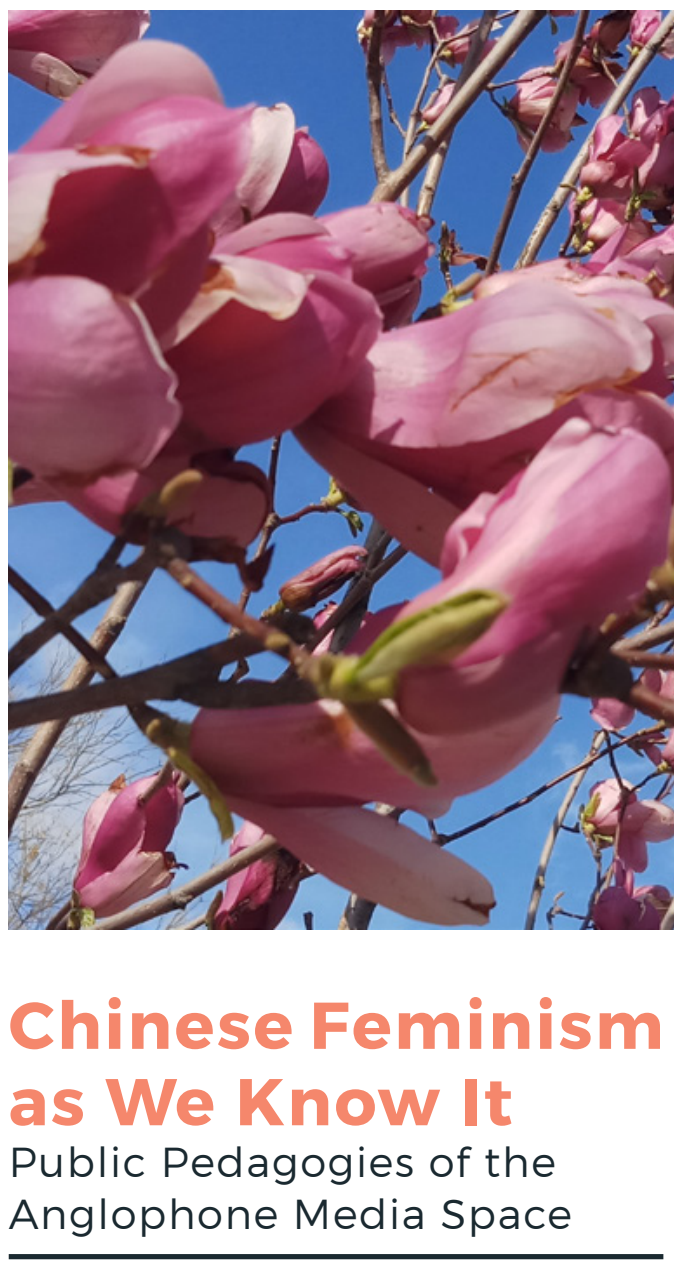

Dušica RISTIVOJEVIĆ

Anglophone media have been reporting about women's activism in China since the mid1990s. While sympathetic media coverage of the public performances of young Chinese feminists in the early 2010s gradually built up popular knowledge, interest, and support among the global audience for grassroots feminist activism in China, the arrest of the 'Feminist Five' in 2015 brought forward a new set of narratives.
We are intellectually and emotionally children of our era, with commitments

and loyalties which come from our involvement in the struggles of the time.

Since we cannot view our own century with the same detachment as the Mauryan Empire or the European wars of religion, we need to make a special mental effort to apply to it the same analysis as we have to the past: retaining

our convictions but recognising that others, and especially future generations, will question them and be puzzled by the importance which we attach to them.

Adam Watson, The Evolution of International Society (1992) 
f the Anglophone media are conceived as a main site of creation and global dissemination of knowledge and meanings, transmitted to both specialist and non-specialist audience, what does an examination of the international press tell us about the lessons we are learning about Chinese feminism?

Writing in 1997 about the media landscape in the United States, Noam Chomsky explained that there are two sectors of the media: the media sources which address and direct the mass audience, and 'the big guys', the ones with the big resources which set the framework in which everyone else operates (Chomsky 1997). To maintain its institutional structure and ideological doctrines, the elite media has been relying on an audience of mostly privileged people operating in the political, business, and educational spheres. In other words, on us.

Fast forward to the present. Technological development and the popularisation of social media may have diversified audiences, but this has not decreased the critical role of big media players in organising the way we think, feel, and look at the world. Quite the opposite: the spread of the Internet as a 'technology of global democracy' (Guldi and Armitage 2014), and the emergence of an increasingly global communicative sphere in which Englishlanguage media play an unprecedentedly authoritative role, have arguably positioned 'the big players' as a crucial site of global public pedagogy. This is due not only to the fact that the reports reach a broad, English-speaking audience located all over the world, but also because the local media in economicallydisadvantaged and non-English speaking parts of the world consult, translate, and further circulate the information produced by the Anglophone agenda-setting media outlets.

So, what have the Anglophone media been telling us about Chinese feminism?

\section{Selective Attention}

Human rights scholar Caroline Fleay (2011) pointed out that, although since 1949 the Chinese Communist Party (CCP) had repeatedly abused human rights of Chinese citizens, before the violent crackdown of the 1989 Tiananmen Square demonstrations there was no significant international criticism of human rights abuses in the country. In her own words: 'In the wake of the massacre, international human rights organisations, some domestic and exiled Chinese human rights actors and various UN human rights agencies continued to investigate and report on human rights abuses in China ... . [T]his transnational network of human rights actors had proven powerful enough to define what were the most important human rights abuses in China' (Fleay 2011, 111). And, I would add, this network has been doing so with the significant-if not straightforwardly pivotalassistance of the Anglophone media.

The importance of 1989 as a turning point in the international criticism of China's human rights record is magnified if the textual and visual content of the influential Anglophone media is observed. Being closely linked to, and cutting across, three intersecting layersthe dynamics of China's (re)positioning in the modern world order; the operation of human rights as global symbolic norms; and the unfolding of transnationally-embedded Chinese social activism - the events of 1989 have been serving as a defining moment for media narratives that intertwined criticism of the CCP and support for Chinese pro-democracy forces within and outside of China. Still, interestingly and importantly, the Anglophone media's introduction of Chinese feminism to a global audience follows a different temporality and modality.

There were some early examples of reporting on Chinese feminism. Anglophone media reports on the Fourth World Conference on Women organised by the United Nations in Beijing in 1995 discussed women's activism in 


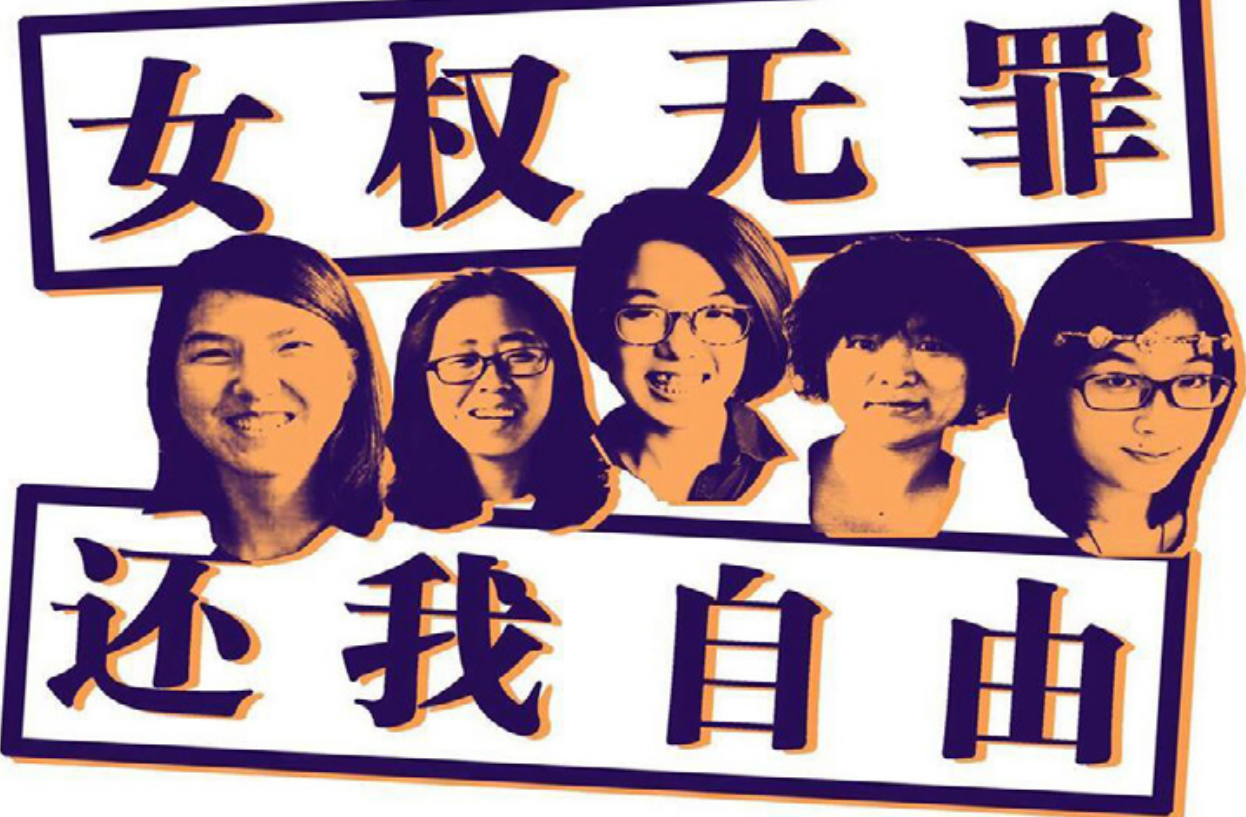

China's Feminist Five.

PC: 3 cr.org.au

China. Also, sympathetic media coverage of the public performances of a group of young Chinese feminists in the early 2010s has been gradually and systematically building up popular knowledge, interest, and support among the global audience for the stream of Chinese feminism not organised under the auspices of the Chinese state. Yet, similar to the way in which the Tiananmen Square demonstrations and the associated representations and meanings generated and disseminated by the Anglophone media became a constitutive trope of global narratives about China and China's dissent, the detention of five young feminists in the spring of 2015 came to be the main reference for succeeding media narratives on feminism in China, and also the starting point for an intensive and forceful creation and dissemination of popular knowledge about Chinese feminism. In the rest of this essay, I will briefly discuss the momentum of the 2015 discursive explosion through which a global non-specialist audience has become familiar with what has often been termed 'young' or 'independent' Chinese feminism.

\section{5 as a Turning Point}

On 7 March 2015, women's rights activists located in several Chinese cities were taken in for questioning about a series of actions against sexual harassment on public transportation that they were planning for the next day. Five young women-Li Tingting (Li Maizi), Wu Rongrong, Zheng Churan, Wei Tingting, and Wang Manwere detained for five weeks, after which they were released on bail. Online Anglophone media outlets-from globally influential media corporations to the ones which target Chinese educated elites and the expat communities- 
dedicated remarkable attention to the detained Chinese feminists. Big players-The New York Times, The Guardian, The Washington Post, $B B C, C N N$, The Associated Press, Deutsche Welle-all regularly fed a global non-specialist audience with interwoven information about the imprisoned women, their transnational support, and China more generally.

On a few occasions before the detention of the Feminist Five, the activities of young Chinese feminists independent from the Partystate had received considerable attention in the Anglophone media. The reports that introduced young feminists to the Englishspeaking audience-especially the texts about the activists participating in the Bloody Brides street performance (Beijing, February 2012) and Occupy the Men's Toilets actions (Guangzhou and Beijing, February 2012)-had a similar structure. The articles usually opened with a description of what the journalist defined as the 'imaginative stunts' of young feminists; this was occasionally accompanied by a brief recapitulation of the continuous tradition of indigenous feminism in China since the turn of the twentieth century, and followed by a long list of disadvantages facing women in contemporary China-including lower wages, the gender gap at birth, problematic media representations, discrimination in the workplace, low number of Chinese women reaching the top positions in politics, etc. These pre-2015 articles generally ended with an optimistic tone and with enthusiastic statements about the members of these feminist groups. The texts disseminated in March and April 2015 had a different tone and structure.

The transnational links established between Chinese feminists and international journalists, activists, and scholars may be one of the reasons why the response of the media to the detention of the Feminist Five was rapid and sustained. Right from the beginning, the media highlighted the mistreatment that the activists were enduring in prison and univocally advocated for the appropriateness of the feminists' actions and, therefore, their innocence and release. As these reports pointed out, the imprisoned women were just planning to disseminate leaflets and stickers, and they should not have been persecuted for this unthreatening mode of activism.

The detained activists came to be known among English-speaking audiences as the 'Feminist Five'. However, the attention that the individual activists received was not equal. Wang Man was probably the activist that we heard the least of, even though her work with women in poor and remote areas was publicly detailed in a letter sent by her family members to the People's Procuratorate of Haidian district, Beijing. Similarly, Wu Rongrong's appeals for the educational rights of migrant workers-information that was also disclosed in the same letter-largely fell outside the scope of media's attention, which instead focussed on her emotional distress and near collapse. Zheng Churan's labour rights activities-her support for strikes, her demands for companies and the government to stop gender discrimination in the employment process-were also very rarely mentioned in popular media outlets.

In contrast, Wei Tingting was introduced to the global public with references to her participation in the women's rights street performances of 2012 mentioned above, but it was her activism related to LGBT issues and AIDS that received most attention from the media. Even more coverage was dedicated to $\mathrm{Li}$ Maizi, who was at the centre of emotionallycoloured media reports, with numerous articles disseminating information not only about her activism, but also about her intimate life: about her abusive father, her loving lesbian partner, and her mischievous and fearless character.

In addition to details about the appealing personalities of the imprisoned feminists and their ill treatment in prison, significant space in the reports was reserved for the international mobilisation of feminists. Texts and images related to the massive mobilisation of women's rights supporters, their petitions, demonstrations, and social media activity were regular during this period. Special emphasis was put on informing and reminding the audience of the support that the detained 
activists received from foreign governments and officials: almost every media outlet reported on the statements made by the European Union Delegation to China and the United Kingdom Foreign Office, the messages sent by Hillary Clinton, the US Secretary of State John Kerry, and the US Vice-president Joe Biden, as well as on the comments by Ambassador Samantha Power, the US Permanent Representative to the United Nations.

\section{Missing Tassels}

One actor has been nearly absent from the media representations of Chinese feminism initiated in the 2010s: the All-China Women's Federation (ACWF), the official, statesponsored mass organisation in charge of representing the interests of Chinese women. Only very brief references to the ACWF were generally included, mainly creating a clearcut antagonistic binary between the ACWF and the detained activists. This was mostly accomplished through the media portrayals of $\mathrm{Li}$ Maizi, which repeatedly raised the Federation's efforts to silence her by offering her a job on the condition that she ceases her protests and social media work-an offer that she refused.

A notable contrast can be seen in the media narratives of 2015. While in and through their narratives about the Feminist Five the Anglophone media downplayed and deprived the ACWF of its feminist legacy and leanings, the image of Hillary Clinton as a global feminist icon was conspicuously inflated through a persistent emphasis on her support for the detained Chinese feminists. Clinton's tweets about the Feminist Five received considerable media attention and directly placed the case at the core of diplomatic relations between China and the United States, contributing to the media constructions of Clinton as an internationallyacclaimed feminist fighter. Knowing in retrospect that soon after her tweets about the Feminist Five, Clinton announced her presidential bid, the media emphasis on her support for the detained activists may be interpreted as both authentic care for the Chinese feminists, and as the beginning of a media discourse about Clinton's long-lasting feminist engagement at both the national and international levels that would become central to her candidacy.

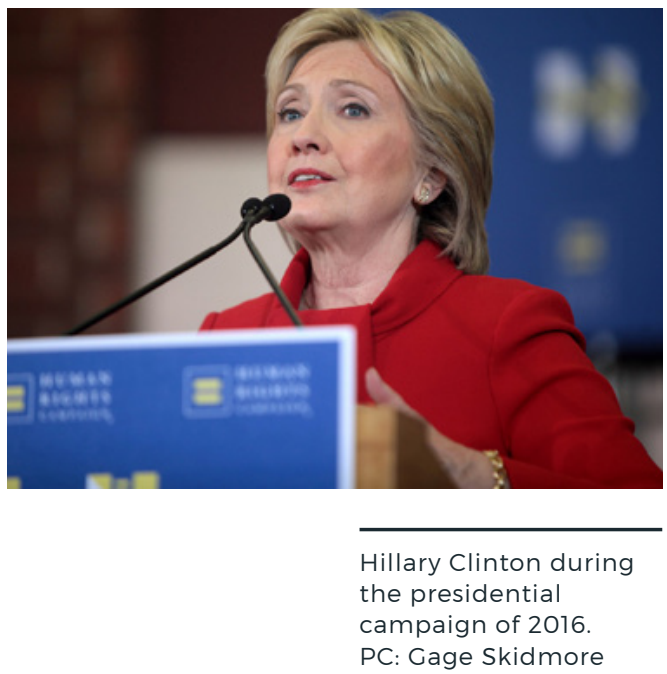

Yet another rather transparent political clue can be found in the ways in which the Anglophone media adjoined the criticism of $\mathrm{Xi}$ Jinping, the Chinese government, and the CCP to the narratives about Chinese feminism. In writing about the detention of the feminists, the articles consistently educated the Anglophone reader about the 'milestone' events, organisations, and people who suffered at the hands of the communist regime. Through these discursive moves, the Feminist Five case was, on the one hand, turned into the foundation for increasing support for persecuted activists, journalists, academics, and organisations; on the other hand, it became a thorough indictment of the abusive power of China's repressive state apparatus. Through both of these processes, it may be argued, the Chinese feminist movement has, for the first time, been firmly placed into a genealogy of unjust and 
cruel treatment of pro-democracy and human rights activists linked by an invisible thread to the iconic 1989 Tiananmen protests.

\section{By Way of Conclusion}

What do the Chinese feminists themselves publicly say about these media narratives of their own endeavours?

Let's listen carefully and attentively to Lü Pin, an experienced and internationally active Chinese feminist activist who founded Feminist Voices in 2009-the largest and most influential digital platform focussed on women's issues in China before being shut down by the Chinese government in 2018. Lü currently resides in the United States, where she publicly talks about Chinese women's rights and continues to follow the feminist movement in China closely.

In a tweet on 2 April 2018, Lü (@pinerpiner) referred to the text on China's \#MeToo movement written by the Chinese feminist Xiao Meili and published by China Change (Xiao 2018). Lü wrote: 'Precious article. One wish of my young feminist friends this year is to elaborate our movement more rather than being represented by others.' What her words point to is not only the feminists' determination to obtain more control over globally-circulating narratives about their activism. They also hint at the feminists' unease with the operating discourses that constitute, and are constituted by, the popular knowledge produced and disseminated by the Anglophone media.

More recently, on the occasion of the 2019 International Women's Day, Lü was interviewed by Siodhbhra Parkin and Jiayun Feng for the online platform SupChina. Replying to a question about her views on the Western media coverage of Chinese feminism, Lü was quoted as saying that the news outlets in the West tend to portray Chinese feminists as victims of government suppression, and that 'using this angle to tell every story about Chinese feminism is boring and actually oversimplifies the situation.' She added that
Western media 'have a tendency of looking at Chinese problems through the lens of politics, but need to understand that oppression is never the core incentive for activists. In China, there is a wide spectrum of protests. Some are political, and some are not ... . [Y] ou can't generalise Chinese activists and associate all of them with politics.' Nonetheless, Lü was not too harsh with the media: while remarking that the Western media's coverage of Chinese feminism 'often seems superficial', she acknowledged the significance of getting the Chinese feminist message out to the Englishspeaking audience and the possibility and need to learn, improve, and solve problems through increased communication.

While bearing in mind that Chinese feminism does not have one face, these learning processes may include the employment of new ways of engagements with feminist narratives that would allow the activists themselves to disseminate their own discourses of Chinese feminism. 